Article

\title{
Impact of Irrigation with Treated Domestic Wastewater on Squash (Cucurbita pepo L.) Fruit and Seed under Semi-Arid Conditions
}

\author{
Ibrahim M. Makhadmeh ${ }^{1}$, Seba F. Gharaiebeh ${ }^{1}$ and Ammar A. Albalasmeh ${ }^{2, *(D)}$ \\ 1 Department of Plant Production, Faculty of Agriculture, Jordan University of Science and Technology, \\ Irbid 22110, Jordan; ibrahimm@just.edu.jo (I.M.M.); sebasun120@yahoo.com (S.F.G.) \\ 2 Department of Natural Resources and Environment, Faculty of Agriculture, Jordan University of Science and \\ Technology, Irbid 22110, Jordan \\ * Correspondence: aalbalasmeh@just.edu.jo; Tel.: +962-27201000 (ext. 22050)
}

Citation: Makhadmeh, I.M.; Gharaiebeh, S.F.; Albalasmeh, A.A. Impact of Irrigation with Treated Domestic Wastewater on Squash (Cucurbita pepo L.) Fruit and Seed under Semi-Arid Conditions. Horticulturae 2021, 7, 226. https:/ / doi.org/10.3390/horticulturae7080226

Academic Editor: Lucia Bortolini

Received: 15 July 2021

Accepted: 2 August 2021

Published: 5 August 2021

Publisher's Note: MDPI stays neutral with regard to jurisdictional claims in published maps and institutional affiliations.

Copyright: (c) 2021 by the authors. Licensee MDPI, Basel, Switzerland. This article is an open access article distributed under the terms and conditions of the Creative Commons Attribution (CC BY) license (https:/ / creativecommons.org/licenses/by/ $4.0 /)$.

\begin{abstract}
The present study investigated the effect of using municipal treated wastewater in irrigation on plant growth and seed quality of squash as compared to fresh water. The physico-chemical properties of both water sources were investigated. Soil, fruits and seeds were tested for heavy metals presence and accumulation. A number of seed composition parameters were also measured. Growth parameters (fruit length, diameter and oven-dried weight) were increased in response to irrigation with treated wastewater as compared to control. All tested heavy metals concentrations were below the toxic limit of the Jordanian standards. Crude protein content was highest ( $41.28 \%)$ in naked seeds under treated wastewater treatment, whereas the lowest content $(33.57 \%)$ was under freshwater treatment of the whole seeds.
\end{abstract}

Keywords: squash seeds; treated wastewater; fresh water

\section{Introduction}

Water availability and scarcity is a major issue worldwide [1]. It has been projected that by 2025 , half of the world's population will live in water scarce areas [2]. This water scarcity would be attributed to non-uniform distribution of water between countries accompanied with variations in rainfall, population growth, water pollution, periodic drought spells and climate changes [1,3-6]. Moreover, increasing the water portion of household and industrial sectors at the expense of the agricultural sector has aggravated water shortage and scarcity problems [1,7].

In order to solve this problem, non-conventional water sources have been suggested, including but not limited to treated wastewater [8-11]. Treated wastewater (TWW) is always available in large quantities. Therefore, it can be used as a non-conventional agricultural water resource for irrigation to conserve fresh water $[1,5,6]$. Using industrial and municipal treated wastewaters to irrigate agricultural fields has become more common in industrialized and developing countries [12,13], particularly in the Mediterranean climate countries, to alleviate the pressure on freshwater sources during drought periods of summer, while the significant rainfall amount during winter is capable of leaching the accumulated salts in soil as a result of using TWW for irrigation [11,14].

Moreover, using wastewater for irrigation has several advantages, including the lowcost water, increasing soil organic matter content which improve soil physical and chemical properties, and reducing the chemical fertilizer used due to the significant nutrient contents in the TWW such as nitrogen $(\mathrm{N})$, phosphorous $(\mathrm{P})$ and potassium $(\mathrm{K})$, which can improve crop production and enhancing soil fertility [3,6,11,15-17]. However, in accompaniment to these beneficial nutrients, wastewater contains other various materials that could be toxic and negatively affect soil, plants and the environment, depending on their source $[1,8,18]$. These various sources of wastewater (i.e., municipal, industrial, and hospital wastewater) 
are all unique in their composition [19]. For example, industrial wastewater contains heavy metals that are beneficial for plant growth at low concentrations [20]. However, accumulation of their concentration in soil leads to an adverse effect on soil and plants, which can result in soil quality degradation and reduction in plant production and quality, which poses a threat to human and animal health $[13,21]$.

Vegetables are a group of crops consumed by all categories of people and can be eaten raw or processed. Therefore, their consumption can cause serious health problems if contaminated [19]. Using wastewater may affect human health as well as the environment because of its content of salts, heavy metals, bacteria and viruses, and contaminants of emerging concern (CECs), depending on the source of wastewater, its composition, and treatment technique [6]. Therefore, many laboratory studies investigated the potential uptake, translocation and accumulation of CECs in plants even at high concentrations that do not exist actually in nature [4,22-29]. Similarly, Naser et al. [30] also reported an accumulation of some heavy metals in leafy vegetables irrigated by municipal and industrial untreated wastewater. Moreover, Brar et al. [31] concluded that potato leaves and tubers accumulated some heavy metals concentrations after irrigation with contaminated wastewater. Fazeli et al. [32] investigated the effect of untreated effluent from a paper mill on rice. They found the concentration of heavy metals in the seeds is significantly lower than that existing in the effluent. Also, Al-Ansari [33] reported an increase in the yield of eggplant after using TWW. Although heavy metal concentrations remained below the permissible limits, the chemical composition of wastewater has to be monitored regularly because of the use of different sources of TWW that comes from different plants which use different treatments (primary, secondary, and tertiary Treatment). Therefore, the objectives of this study were to determine the growth of squash plants irrigated by treated municipal wastewater and to evaluate seed quality under semi-arid climate conditions.

\section{Materials and Methods}

\subsection{Experimental Site}

The experiment was carried out in an open field of the Faculty of Agriculture $\left(32^{\circ} 28^{\prime} 01.6^{\prime \prime} \mathrm{N}\right.$ $35^{\circ} 58^{\prime} 31.1^{\prime \prime}$ E) Jordan University of Science and Technology (JUST), Jordan during the year 2014. Eight growing beds per each season were prepared $(7.7 \mathrm{~m}$ long, $0.7 \mathrm{~m}$ width and $0.45 \mathrm{~m}$ height) and filled with topsoil collected from same location, containing on average $48 \%$ clay, $37 \%$ silt, and $15 \%$ sand. The soil has an electrical conductivity (EC) of $2.10 \mathrm{dS} \mathrm{m}^{-1}$ and $\mathrm{pH}$ of 7.95 .

Certified squash seeds (Cucurbita pepo L.) cv. Shorouq (Syngenta) were planted directly in the soil; two seeds were planted every $40 \mathrm{~cm}$ close to the emitters of the irrigation pipeline (16 plants per bed). Then, soil was covered with a black plastic sheet to reduce the evaporation in order to reduce water consumption and prevent the growth of weeds. Immediately after sowing, all seeds were irrigated with fresh water until seedlings emerged and developed the first true leaves, after which seedlings were thinned out into one plant. Two types of water quality have been used in the experiment, freshwater (FW) and treated wastewater (TWW) produced from secondary treatment (Table 1). Experimental design was Randomized Complete Block Design (RCBD) with four replicates.

\subsection{Fruit Growth}

Fruit diameter was measured daily using a digital caliper at the swollen zone of fruit, whereas fruit length was measured from the pedicle zone to the blossom end. Samples were selected randomly from replicates and marked for daily diameter measurement until they reached maturity, by changing color with hard leathery rind and withering of the mother plant. At the end of season, all matured fruit were collected and sliced to measure the fresh and dry weight. 
Table 1. Mean values of selected properties of the used TWW and FW.

\begin{tabular}{cccc}
\hline Parameter & Unit & TWW & FW \\
\hline $\mathrm{pH}$ & - & 7.8 & 7.4 \\
$\mathrm{EC}$ & $\mathrm{dS} \mathrm{m}^{-1}$ & 1.5 & 0.6 \\
\hline $\mathrm{Na}$ & & 161.3 & 22.9 \\
$\mathrm{NO}_{3}^{-}$ & & 38.3 & 20.1 \\
$\mathrm{PO}_{4}{ }^{-2}$ & & 4.0 & $\mathrm{udl}$ \\
$\mathrm{K}$ & & 37.7 & 3.5 \\
$\mathrm{Ca}$ & & 70.1 & 25.1 \\
$\mathrm{Mg}$ & $\mathrm{mg} \mathrm{L}^{-1}$ & 41.3 & 30.8 \\
$\mathrm{Cl}$ & & 255.8 & 51.3 \\
$\mathrm{DOM}$ & & 70 & nd \\
$\mathrm{TSS}$ & & 30 & $\mathrm{nd}$ \\
$\mathrm{TDS}$ & 1050 & 500 \\
$\mathrm{BOD}$ & 15 & $\mathrm{nd}$ \\
$\mathrm{COD}$ & & 57 & $\mathrm{nd}$ \\
$\mathrm{Cd}$ & & $<0.0003$ & $<0.0003$ \\
$\mathrm{Zn}$ & & 0.017 & 0.020 \\
$\mathrm{Cu}$ & 0.018 & 0.010 \\
$\mathrm{~Pb}$ & 0.004 & $<0.0003$ \\
$\mathrm{Cr}$ & $\mathrm{udl}$ & $\mathrm{Udl}$
\end{tabular}

nd: not determined; udl: under detection limit; EC: electrical conductivity; DOM: dissolved organic matter; TSS: total suspended solid; TDS: total dissolved solid; BOD: biological oxygen demand; COD: chemical oxygen demand.

\subsection{Heavy Metal Accumulation in Soil, Fruit and Seed}

A subset of fruit, seed and soil was selected randomly from both water sources, control (FW) and wastewater treatments, for analysis of major heavy metals $(\mathrm{Zn}, \mathrm{Mn}, \mathrm{Fe}, \mathrm{Cu}, \mathrm{Cr}$, $\mathrm{As}, \mathrm{Ni}, \mathrm{Cd}$ ) using an atomic absorption instrument following Abbruzzini et al. [34]. For soil sample preparation, $2 \mathrm{gm}$ was taken from each sample, then dissolved in $5 \mathrm{~mL} \mathrm{HNO}_{3}$, $0.5 \mathrm{~mL} \mathrm{HF}$, and $0.5 \mathrm{~mL} \mathrm{HCl}$ in a Teflon vessel. Then, $0.5 \mathrm{gm}$ was taken from each fruit and seed samples, which had been oven-dried beforehand. Samples were dissolved in $6 \mathrm{~mL}$ $69 \% \mathrm{HNO}_{3}$ and $3 \mathrm{~mL} \mathrm{HCl}$ in a Teflon vessel in a Microwave Digestion System. The digested samples were then transferred into a Teflon beaker and the volume was completed to $50 \mathrm{~mL}$ with de-ionized water. The digested solution was filtered by using $0.45 \mu \mathrm{m}$ syringe filter and stored in $50 \mathrm{~mL}$ polypropylene tubes to be analyzed.

\subsection{Chemical Analysis of the Seeds}

The seed proximate composition was analyzed following the standard official methods of the Association of Official Analytical Chemists [35].

Crude protein was calculated from the nitrogen content by Kjeldahl method using factor 6.25 (method 979.09). Ash content was evaluated by incinerating a few grams from each sample at $550{ }^{\circ} \mathrm{C}$ in a muffle furnace for $6 \mathrm{~h}$ (method 923.03). Moisture was determined gravimetrically to a constant weight in an oven at $100{ }^{\circ} \mathrm{C}$ (method 925.10). Crude fat of the sample was determined according to the Soxhlet extraction method by mixing of the fine powder of the sample with ether extract solution (method 960.39). The fat content was determined gravimetrically after the extract was dried to a constant weight.

\subsection{Mineral Composition of the Seeds}

To determine the mineral content of squash seeds, $3 \mathrm{~g}$ from each sample was incinerated in a furnace at $500{ }^{\circ} \mathrm{C}$ and the residues dissolved in $50 \mathrm{~mL}$ of $2.5 \% \mathrm{HNO}_{3}$ solution. The concentrations of $\mathrm{Na}, \mathrm{Ca}, \mathrm{K}, \mathrm{Li}$ and $\mathrm{Ba}$ was determined using a flame photometer following [36]. Phosphorus was determined using the ammonium molybdate/ammonium vanadate method of Chapman and Pratt [37]. 


\subsection{Statistical Analysis}

Data were subjected to analysis of variance (ANOVA) by One-way ANOVA using SPSS (Statistical Package for the Social Sciences). Mean comparison was performed using the Fishers Least Significant Difference (LSD) at $p \leq 0.05$.

\section{Results and Discussion}

\subsection{Fruit Growth}

Table 2 shows the effect of irrigation water treatment on fruit length, diameter and oven-dried weight. The results show that TWW as irrigation water significantly increased the length and diameter of the squash fruit. The average length was 25 and $20.7 \mathrm{~cm}$ for the TWW and FW treatments, respectively. Similarly, average diameter was 10.2 and $8.8 \mathrm{~cm}$ for the TWW and FW treatments, respectively. These measurements were reflected on the oven-dried weight for each treatment; the average oven-dried weight was 41.9 and $27.5 \mathrm{~g} \mathrm{~cm}$ for the TWW and FW treatments, respectively. This increase could be explained by the high nutrient content of TWW which plays a crucial role in plant growth improvement [38-40]. These results are in agreement with Al-Lahham et al. [41], who reported an increase in the diameter of tomato after using TWW in irrigation compared to FW. Similarly, Kumar et al. [40] reported a significant increase in the growth parameters of cauliflower irrigated by TWW compared to well water. They attributed this difference to the nutrients content in the TWW which make the farmers attracted to the use of TWW.

Table 2. Mean values of fruit length, diameter and oven-dried weight of the used TWW and FW.

\begin{tabular}{cccc}
\hline & FW $\left(\right.$ SE $\left.^{2}\right)$ & TWW (SE) & $p$-Value \\
\hline Fruit mean ${ }^{1}$ length $(\mathrm{cm})$ & $20.7(1.602)$ & $25.0(1.954)$ & 0.151 \\
\hline Fruit mean ${ }^{1}$ diameter $(\mathrm{cm})$ & $8.8(0.708)$ & $10.2(0.835)$ & 0.253 \\
\hline Oven-dried mean ${ }^{1}$ weight $(\mathrm{g})$ & $27.5(0.143)$ & $41.9(0.128)$ & $<0.001{ }^{*}$ \\
\hline${ }^{1}$ mean is the average of 5 fruit ${ }^{2}$ standard error. ${ }^{*}$ statistically different.
\end{tabular}

${ }^{1}$ mean is the average of 5 fruit ${ }^{2}$ standard error. * statistically different.

\subsection{Heavy Metal Accumulation in Soil, Fruit and Seed}

The effect of using TWW on heavy metals accumulation in soil, fruits and seeds is tabulated in Table 3. The results show that there were no significant differences in the accumulation of heavy metals in soil, fruits and seeds between the TWW and FW. Moreover, all the concentrations reported in Table 3 are below the toxic limit of the Jordanian standards (Jordanian standard for reclaimed wastewater, Ministry of Water and Irrigation, 893/2006). These results could be explained by the fact that the TWW used in the experiment is municipal, not industrial, wastewater. Therefore, it contains very low concentrations of heavy metals (Table 1). On the other hand, Naz et al. [42], reported that industrial wastewater contains heavy metals in concentrations considered toxic for plants. These results are in line with the results obtained by Zavadil [43], who reported no significant effect of using TWW on accumulation of heavy metals in lettuce, radish, carrot and potatoes. Similarly, Hussain et al. [44] showed that using TWW to irrigate radish, spinach and carrot plants showed lower levels of heavy metals (i.e., $\mathrm{Cd}, \mathrm{Co}, \mathrm{Cu}, \mathrm{Cr}, \mathrm{Mn}, \mathrm{Ni}, \mathrm{Pb}$ and $\mathrm{Zn}$ ), below toxic limits. Moreover, Kiziloglu et al. [45] reported that TWW can be used for irrigating crops for long terms and no accumulation of heavy metals occurred in cauliflower and red cabbage. A similar conclusion was drawn by Kim et al. [46], that using treated domestic wastewater in agriculture is safe for human consumption. 
Table 3. Effect of using TWW and FW on heavy metal accumulation in soil, fruits and seeds.

\begin{tabular}{cccccccc}
\hline \multirow{2}{*}{$\begin{array}{c}\text { Heavy } \\
\text { Metal }\end{array}$} & \multirow{2}{*}{ Unit } & \multicolumn{2}{c}{ Soil } & \multicolumn{2}{c}{ Fruits } & \multicolumn{2}{c}{ Seeds } \\
\cline { 3 - 7 } & & FW & TWW & FW & TWW & FW & TWW \\
\hline $\mathrm{Ni}$ & & 0.028 & 0.032 & 0.003 & 0.003 & 0.003 & 0.002 \\
$\mathrm{Zn}$ & & 0.081 & 0.079 & 0.044 & 0.052 & 0.114 & 0.116 \\
$\mathrm{Cu}$ & $\mathrm{ppm}$ & 0.022 & 0.021 & 0.026 & 0.039 & 0.038 & 0.042 \\
$\mathrm{Mn}$ & & 0.303 & 0.329 & 0.000 & 0.000 & 0.026 & 0.040 \\
$\mathrm{Fe}$ & & 42.339 & 42.632 & 0.150 & 0.183 & 0.153 & 0.437 \\
\hline $\mathrm{Cd}$ & & 7.032 & 7.893 & 0.770 & 1.232 & 0.158 & 0.295 \\
$\mathrm{Cr}$ & $\mathrm{ppb}$ & 205.205 & 204.376 & 0.913 & 1.304 & 0.254 & 1.859 \\
$\mathrm{As}$ & & 653.236 & 625.004 & 2.056 & 3.782 & 1.509 & 2.292 \\
\hline
\end{tabular}

\subsection{Seed Proximate Analysis}

The total seed number of plants irrigated using FW was 484 seeds, compared to 774 seeds of same number of plants irrigated by TWW. This means that the usage of TWW resulted in a significant increase in the number of seed production. This result is comparable with Day et al. [47], who reported a significant increase in the seed yield as a result of using wastewater in irrigating plants.

Table 4 shows the effect of using TWW and FW on seed dry matter, crude fat and crude protein contents. The seeds of plants irrigated by TWW had higher dry matter percentage $(90.23 \%)$ than that irrigated by FW $(87.96 \%)$. Similarly, dry matter of the naked seeds was higher in the TWW treatment (68.18\%) compared to the FW plants $(66.43 \%)$. Several studies reported an increase in the dry matter as a result of using TWW in irrigation plants because of its content of the nutritional elements required by plants to grow [48-50].

Table 4. Effect of using TWW and FW on seed proximate analysis.

\begin{tabular}{ccccccc}
\hline & & \multicolumn{3}{c}{ F.W } & \multicolumn{1}{c}{ T.W.W } \\
\cline { 3 - 7 } & & Mean & SE $^{4}$ & Mean & SE & $p$-Value \\
\hline \multirow{3}{*}{ Whole } & $\begin{array}{c}\text { Actual DM } \\
1\end{array}$ & 87.96 & 3.719 & 90.23 & 4.807 & 0.730 \\
& $\mathrm{CP}^{2}$ & 33.57 & 1.574 & 35.85 & 0.525 & 0.254 \\
& $\mathrm{CF}^{3}$ & 28.45 & 1.628 & 29.84 & 1.165 & 0.549 \\
\hline \multirow{3}{*}{ Naked } & Actual DM & 66.43 & 1.569 & 68.18 & 6.325 & 0.743 \\
& CP\% & 39.44 & 1.349 & 41.28 & 0.837 & 0.309 \\
& CF\% & 36.89 & 0.444 & 34.57 & 1.775 & 0.246 \\
\hline
\end{tabular}

${ }^{1}$ dry matter; ${ }^{2}$ crude protein; ${ }^{3}$ crude fat and ${ }^{4}$ Standard Error.

According to Table 4, the highest crude protein (CP) content in the squash seeds was found in naked seeds of the plants that were irrigated by TWW $(41.28 \%)$, whereas the lowest content was found under FW treatment of the whole seeds $(33.57 \%)$. This increase in crude protein percentage could be linked to the availability of various amounts of elements in the TWW such as nitrogen, potassium and phosphorous.

These results are in agreement with Aghtape et al. [51] who studied the effects of irrigation using wastewater on some forage characteristics of foxtail millet (Setaria italic). They found that crude protein percentage was the highest under TWW treatment for all growing stages. Similarly, Ghanbari et al. [52] reported a higher percentage of crude protein using TWW compared to FW in wheat.

It is a well-known fact that seeds contain storage food in their cotyledons such as lipids, proteins and mainly carbohydrates. Crude fat content of squash seeds is tabulated in Table 4. The highest crude fat content was found under FW treatment of the naked seeds $(36.89 \%)$ whereas the lowest content was found under FW treatment of the whole seeds $(28.45 \%)$. However, these differences are not statistically significant. These results are in 
agreement with the results of Kiziloglu et al. [53], who found that TWW had no significant difference on fat content.

\subsection{Mineral Composition of the Seeds}

Table 5 shows the effect of using TWW and FW on seed mineral composition $(\mathrm{Na}, \mathrm{K}$, $\mathrm{Ca}$ and $\mathrm{P}$ ). The highest concentration of sodium $(\mathrm{Na})$ was found in the plants irrigated by TWW in the whole and naked seeds, at 730.49 and $628.57 \mathrm{mg} / \mathrm{L}$, respectively (Table 5). Similarly, the highest concentration of potassium $(\mathrm{k})$ was found in the plants irrigated by TWW in the whole and naked seeds, at 5957.4 and $4350.3 \mathrm{mg} / \mathrm{L}$, respectively. Also, the highest concentration of calcium (Ca) was found in the plants irrigated by TWW in the naked seeds $(149.73 \mathrm{mg} / \mathrm{L})$ and lowest concentration in the plants irrigated by TWW in the whole seeds $(114.21 \mathrm{mg} / \mathrm{L})$. Moreover, phosphorous $(\mathrm{P})$ concentration in the plants irrigated by TWW was higher compared to plants irrigated by FW, at 3.64 and $1.29 \mathrm{mg} / \mathrm{L}$, respectively.

Table 5. Effect of using TWW and FW on mineral composition of the squash seeds.

\begin{tabular}{cccccc}
\hline \multirow{2}{*}{} & & Na & K & Ca & $p$ \\
\cline { 3 - 6 } & & \multicolumn{3}{c}{$\mathbf{m g} / \mathbf{L}$} \\
\hline \multirow{2}{*}{ Whole } & TWW & 730.49 & 5957.4 & 114.21 & 3.64 \\
& FW & 537.5 & 3545.5 & 136.36 & 2.03 \\
\hline \multirow{2}{*}{ Naked } & TWW & 628.57 & 4350.3 & 149.73 & 3.58 \\
& FW & 571.79 & 3876.7 & 114.66 & 1.29 \\
\hline
\end{tabular}

Khan et al. [54], who studied the nutrient content of sunflowers (Helianthus Annuus L.) irrigated by TWW, found that using TWW in irrigation caused a significant increase in the concentration of $\mathrm{Na}$ and $\mathrm{Ca}$. Similarly, Omeir et al. [55] found a higher phosphorus content in the seeds of plants irrigated by TWW compared to FW.

\subsection{Effect of Treated Wastewater on Fruit and Seed of Mycotoxin Availability}

The effect of irrigating squash plants by municipal TWW on mycotoxin content in seed and fruit is tabulated in Table 6 . There was no significant difference in the aflatoxins content (B1, B2, G1, G2 and M1) for both water sources (FW and TWW) where both values were much below the acceptable level $(4-15 \mu \mathrm{g} / \mathrm{kg})$ set by the European Union [56].

Table 6. Effect of water source on mycotoxin in seed.

\begin{tabular}{cccccc}
\hline & \multicolumn{2}{c}{ FW } & \multicolumn{3}{c}{ TWW } \\
\hline Aflatoxin & Mean & SE & Mean & SE & $p$-Value \\
\hline B1 & 0.357 & 0.0049 & 0.361 & 0.0102 & 0.723 \\
B2 & BDL & BDL & BDL & - & - \\
G1 & 0.365 & 0.0041 & 0.359 & 0.0032 & 0.260 \\
G2 & BDL & BDL & BDL & - & - \\
M1 & 0.097 & 0.0635 & BDL & - & 0.170 \\
\hline
\end{tabular}

SE: standard error; BDL: Below detection limit.

These results could be explained by the fact that the origin of the used wastewater was a municipal source, and it was treated by a secondary treatment plant.

\section{Conclusions}

The TWW, depending on its composition to original source (municipal or industrial), can supply plants with the required nutrients for growth. High concentrations of these nutrients probably stimulate plant growth in the TWW treatment compared to the FW treatment. According to the results, plant growth was satisfactory in irrigation with TWW 
treatment. Therefore, municipal TWW could be noticeable as a source of irrigation in agriculture, especially under arid and semi-arid climates where water is scarce.

Author Contributions: Conceptualization, I.M.M.; methodology, I.M.M. and S.F.G.; validation, I.M.M. and S.F.G.; formal analysis, I.M.M., S.F.G. and A.A.A.; investigation, S.F.G.; resources, I.M.M.; data curation, I.M.M., S.F.G. and A.A.A.; writing-original draft preparation, A.A.A. and I.M.M.; writing-review and editing, A.A.A., I.M.M. and S.F.G. visualization, A.A.A.; supervision, I.M.M.; project administration, I.M.M.; funding acquisition, I.M.M. All authors have read and agreed to the published version of the manuscript.

Funding: This research was funded by Deanship of Research at Jordan University of Science and Technology (JUST), grant number 258/2015 and the APC was partially funded by JUST.

Institutional Review Board Statement: Not applicable.

Informed Consent Statement: Not applicable.

Data Availability Statement: The authors confirm that the data supporting the findings of this study are available within the article.

Acknowledgments: The authors would like to acknowledge the Deanship of Research at JUST for the financial support of this study.

Conflicts of Interest: The authors declare no conflict of interest.

\section{References}

1. Rasheed, F.; Zafar, Z.; Waseem, Z.A.; Rafay, M.; Abdullah, M.; Salam, M.M.A.; Mohsin, M.; Khan, W.R. Phytoaccumulation of Zn, $\mathrm{Pb}$, and $\mathrm{Cd}$ in Conocarpus lancifolius irrigated with wastewater: Does physiological response influence heavy metal uptake? Int. J. Phytoremediat. 2020, 22, 287-294. [CrossRef]

2. Quist-Jensen, C.A.; Macedonio, F.; Drioli, E. Membrane technology for water production in agriculture: Desalination and wastewater reuse. Desalination 2015, 364, 17-32. [CrossRef]

3. Farhadkhani, M.; Nikaeen, M.; Yadegarfar, G.; Hatamzadeh, M.; Pourmohammadbagher, H.; Sahbaei, Z.; Rahmani, H.R. Effects of irrigation with secondary treated wastewater on physicochemical and microbial properties of soil and produce safety in a semi-arid area. Water Res. 2018, 144, 356-364. [CrossRef]

4. Libutti, A.; Gatta, G.; Gagliardi, A.; Vergine, P.; Pollice, A.; Beneduce, L.; Disciglio, G.; Tarantino, E. Agro-industrial wastewater reuse for irrigation of a vegetable crop succession under Mediterranean conditions. Agric. Water Manag. 2018, 196, 1-14. [CrossRef]

5. Mkhinini, M.; Boughattas, I.; Hattab, S.; Amamou, C.; Banni, M. Effect of treated wastewater irrigation on physiological and agronomic properties of beans Vicia faba. Int. J. Environ. Agric. Biotechnol. 2018, 3, 1414-1420. [CrossRef]

6. Atamaleki, A.; Yazdanbakhsh, A.; Fakhri, Y.; Mahdipour, F.; Khodakarim, S.; Khaneghah, A.M. The concentration of potentially toxic elements (PTEs) in the onion and tomato irrigated by wastewater: A systematic review; meta-analysis and health risk assessment. Food Res. Int. 2019, 125, 108518. [CrossRef] [PubMed]

7. Fatta-Kassinos, D.; Kalavrouziotis, I.K.; Koukoulakis, P.H.; Vasquez, M.I. The risks associated with wastewater reuse and xenobiotics in the agroecological environment. Sci. Total Environ. 2011, 409, 3555-3563. [CrossRef] [PubMed]

8. Picó, Y.; Alvarez-Ruiz, R.; Alfarhan, A.H.; El-Sheikh, M.A.; Alobaid, S.M.; Barceló, D. Uptake and accumulation of emerging contaminants in soil and plant treated with wastewater under real-world environmental conditions in the Al Hayer area (Saudi Arabia). Sci. Total Environ. 2019, 652, 562-572. [CrossRef]

9. Mohawesh, O.; Albalasmeh, A.; Al-Hamaiedeh, H.; Qaraleh, S.; Maaitah, O.; Bawalize, A.; Almajali, D. Controlled land application of olive mill wastewater (OMW): Enhance soil indices and barley growth performance in arid environments. Water Air Soil Pollut. 2020, 231. [CrossRef]

10. Mohawesh, O.; Al-Hamaiedeh, H.; Albalasmeh, A.; Qaraleh, S.; Haddadin, M. Effect of olive mill wastewater (OMW) application on soil properties and wheat growth performance under rain-fed conditions. Water Air Soil Pollut. 2019, 230, 160. [CrossRef]

11. Albalasmeh, A.; Gharaibeh, M.; Alghzawi, M.; Morbidelli, R.; Saltalippi, C.; Ghezzehei, T.; Flammini, A. Using wastewater in irrigation: The effects on infiltration process in a clayey soil. Water 2020, 12, 968. [CrossRef]

12. Tunc, T.; Sahin, U. Yield and heavy metal content of wastewater-irrigated cauliflower and soil chemical properties. Commun. Soil Sci. Plant Anal. 2017, 48, 1194-1211. [CrossRef]

13. Gatta, G.; Gagliardi, A.; Disciglio, G.; Lonigro, A.; Francavilla, M.; Tarantino, E.; Giuliani, M. Irrigation with treated municipal wastewater on artichoke crop: Assessment of soil and yield heavy metal content and human risk. Water 2018, 10, 255. [CrossRef]

14. Gharaibeh, M.A.; Eltaif, N.I.; Al-Abdullah, B. Impact of field application of treated wastewater on hydraulic properties of vertisols. Water Air Soil Pollut. 2007, 184, 347-353. [CrossRef] 
15. Prazeres, A.R.; Rivas, J.; Almeida, M.A.; Patanita, M.; Dôres, J.; Carvalho, F. Agricultural reuse of cheese whey wastewater treated by $\mathrm{NaOH}$ precipitation for tomato production under several saline conditions and sludge management. Agric. Water Manag. 2016, 167, 62-74. [CrossRef]

16. Albalasmeh, A.A.; Ghezzehei, T.A. Interplay between soil drying and root exudation in rhizosheath development. Plant Soil 2014, 374, 739-751. [CrossRef]

17. Gharaibeh, M.A.; Ghezzehei, T.A.; Albalasmeh, A.A.; Alghzawi, M.Z. Alteration of physical and chemical characteristics of clayey soils by irrigation with treated waste water. Geoderma 2016, 276, 33-40. [CrossRef]

18. Khawla, K.; Besma, K.; Enrique, M.; Mohamed, H. Accumulation of trace elements by corn (Zea mays) under irrigation with treated wastewater using different irrigation methods. Ecotoxicol. Environ. Saf. 2019, 170, 530-537. [CrossRef]

19. Inyinbor, A.A.; Bello, O.S.; Oluyori, A.P.; Inyinbor, H.E.; Fadiji, A.E. Wastewater conservation and reuse in quality vegetable cultivation: Overview, challenges and future prospects. Food Control 2019, 98, 489-500. [CrossRef]

20. Almuktar, S.A.A.A.N.; Scholz, M. Mineral and biological contamination of soil and Capsicum annuum irrigated with recycled domestic wastewater. Agric. Water Manag. 2016, 167, 95-109. [CrossRef]

21. Gatta, G.; Libutti, A.; Gagliardi, A.; Disciglio, G.; Beneduce, L.; d'Antuono, M.; Rendina, M.; Tarantino, E. Effects of treated agro-industrial wastewater irrigation on tomato processing quality. Ital. J. Agron. 2015, 10, 97-100. [CrossRef]

22. Di Baccio, D.; Pietrini, F.; Bertolotto, P.; Pérez, S.; Barcelò, D.; Zacchini, M.; Donati, E. Response of Lemna gibba L. to high and environmentally relevant concentrations of ibuprofen: Removal, metabolism and morpho-physiological traits for biomonitoring of emerging contaminants. Sci. Total Environ. 2017, 584, 363-373. [CrossRef] [PubMed]

23. Dudley, S.; Sun, C.; Jiang, J.; Gan, J. Metabolism of sulfamethoxazole in Arabidopsis thaliana cells and cucumber seedlings. Environ. Pollut. 2018, 242, 1748-1757. [CrossRef]

24. Fu, Q.; Ye, Q.; Zhang, J.; Richards, J.; Borchardt, D.; Gan, J. Diclofenac in Arabidopsis cells: Rapid formation of conjugates. Environ. Pollut. 2017, 222, 383-392. [CrossRef] [PubMed]

25. Madikizela, L.M.; Ncube, S.; Chimuka, L. Uptake of pharmaceuticals by plants grown under hydroponic conditions and natural occurring plant species: A review. Sci. Total Environ. 2018, 636, 477-486. [CrossRef] [PubMed]

26. Montemurro, N.; Postigo, C.; Lonigro, A.; Perez, S.; Barceló, D. Development and validation of an analytical method based on liquid chromatography-tandem mass spectrometry detection for the simultaneous determination of 13 relevant wastewaterderived contaminants in lettuce. Anal. Bioanal. Chem. 2017, 409, 5375-5387. [CrossRef]

27. Picó, Y.; Alvarez-Ruiz, R.; Wijaya, L.; Alfarhan, A.; Alyemeni, M.; Barceló, D. Analysis of ibuprofen and its main metabolites in roots, shoots, and seeds of cowpea (Vigna unguiculata L. Walp) using liquid chromatography-quadrupole time-of-flight mass spectrometry: Uptake, metabolism, and translocation. Anal. Bioanal. Chem. 2018, 410, 1163-1176. [CrossRef]

28. Sun, C.; Dudley, S.; McGinnis, M.; Trumble, J.; Gan, J. Acetaminophen detoxification in cucumber plants via induction of glutathione S-transferases. Sci. Total Environ. 2019, 649, 431-439. [CrossRef]

29. Sun, C.; Dudley, S.; Trumble, J.; Gan, J. Pharmaceutical and personal care products-induced stress symptoms and detoxification mechanisms in cucumber plants. Environ. Pollut. 2018, 234, 39-47. [CrossRef]

30. Naser, H.M.; Rahman, M.Z.; Sultana, S.; Quddus, M.A.; Hossain, M.A. Heavy metal accumulation in leafy vegetables grown in industrial areas under varying levels of pollution. Bangladesh J. Agric. Res. 2018, 43, 39-51. [CrossRef]

31. Brar, M.S.; Malhi, S.S.; Singh, A.P.; Arora, C.L.; Gill, K.S. Sewage water irrigation effects on some potentially toxic trace elements in soil and potato plants in northwestern India. Can. J. Soil Sci. 2000, 80, 465-471. [CrossRef]

32. Fazeli, M.S.; Khosravan, F.; Hossini, M.; Sathyanarayan, S.; Satish, P.N. Enrichment of heavy metals in paddy crops irrigated by paper mill effluents near Nanjangud, Mysore District, Karnatake, India. Environ. Geol. 1998, 34, 297-302. [CrossRef]

33. Al-Ansari, N.; Aldardor, W.; Siergieiev, D.; Knutsson, S. Effect of treated wastewater irrigation on vegetables. J. Environ. Hydrol. 2013, 21. [CrossRef]

34. Abbruzzini, T.F.; Silva, C.A.; de Andrade, D.A.; de Oliveira Carneiro, W.J. Influence of digestion methods on the recovery of Iron, Zinc, Nickel, Chromium, Cadmium and Lead contents in 11 organic residues. Rev. Bras. Ciência Solo 2014, 38, 166-176. [CrossRef]

35. AOAC. Official Methods of Analysis, 16th ed.; Association of Official Analytical Chemists: Washington, DC, USA, 1999.

36. Williams, J.P.; Adams, P.B. Flame spectrophotometric analysis of glasses and ores: I, Lithium, Sodium, Potassium, Rubidium, and Cesium. J. Am. Ceram. Soc. 1954, 37, 306-311. [CrossRef]

37. Chapman, H.D.; Pratt, F. Ammonium vandate-molybdate method for determination of phosphorus. In Methods of Analysis for Soils, Plants and Water; California University-Agriculture Division: Oakland, CA, USA, 1961; pp. $184-203$.

38. Maurer, M.A.; Davies, F.S.; Graetz, D.A. Reclaimed wastewater irrigation and fertilization of mature "redblush" grapefruit trees on spodosols in florida. J. Am. Soc. Hortic. Sci. 1995, 120, 394-402. [CrossRef]

39. Mohammad, M.J.; Mazahreh, N. Changes in soil fertility parameters in response to irrigation of forage crops with secondary treated wastewater. Commun. Soil Sci. Plant Anal. 2003, 34, 1281-1294. [CrossRef]

40. Kumar, V.; Thakur, R.K.; Kumar, P. Assessment of heavy metals uptake by cauliflower (Brassica oleracea var. botrytis) grown in integrated industrial effluent irrigated soils: A prediction modeling study. Sci. Hortic. 2019, 257, 108682. [CrossRef]

41. Al-Lahham, O.; El Assi, N.M.; Fayyad, M. Impact of treated wastewater irrigation on quality attributes and contamination of tomato fruit. Agric. Water Manag. 2003, 61, 51-62. [CrossRef]

42. Naz, H.; Naz, A.; Ashraf, S. Impact of heavy metal toxicity to plant growth and nodulation in Chickpea grown under heavy metal stress. Int. J. Res. Emerg. Sci. Technol. 2015, 2, 248-260. 
43. Zavadil, J. The effect of municipal wastewater irrigation on the yield and quality of vegetables and crops. Soil Water Res. 2009, 4, 91-103. [CrossRef]

44. Hussain, A.; Priyadarshi, M.; Dubey, S. Experimental study on accumulation of heavy metals in vegetables irrigated with treated wastewater. Appl. Water Sci. 2019, 9, 122. [CrossRef]

45. Kiziloglu, F.; Turan, M.; Sahin, U.; Kuslu, Y.; Dursun, A. Effects of untreated and treated wastewater irrigation on some chemical properties of cauliflower (Brassica olerecea L. var. botrytis) and red cabbage (Brassica olerecea L. var. rubra) grown on calcareous soil in Turkey. Agric. Water Manag. 2008, 95, 716-724. [CrossRef]

46. Kim, H.K.; Jang, T.I.; Kim, S.M.; Park, S.W. Impact of domestic wastewater irrigation on heavy metal contamination in soil and vegetables. Environ. Earth Sci 2015, 73, 2377-2383. [CrossRef]

47. Day, A.; Taher, F.; Katterman, F. Influence of treated municipal wastewater on growth fiber, acid soluble nucleotide, protein and amino acid content in wheat grain. J. Environ. Qual. 1975, 4, 167-169. [CrossRef]

48. Seleiman, M.; Al-Suhaibani, N.; El-Hendawy, S.; Abdella, K.; Alotaibi, M. Impacts of long- and short-term of irrigation with treated wastewater and synthetic fertilizers on the growth, biomass, heavy metal content, and energy traits of three potential bioenergy crops in arid regions. Energies 2021, 14, 3037. [CrossRef]

49. Tzortzakis, N.; Saridakis, C.; Chrysargyris, A. Treated wastewater and fertigation applied for greenhouse tomato cultivation grown in municipal solid waste compost and soil mixtures. Sustainability 2020, 12, 4287. [CrossRef]

50. Mousavi, S.; Galavi, M.; Eskandari, H. Effects of treated municipal wastewater on fluctuation trend of leaf area index and quality of Maize (Zea Mays). Water Sci. Technol. 2013, 67, 797-802. [CrossRef]

51. Aghtape, A.; Ghanbari, A.; Sirousmehr, A.; Siahsar, B.; Asgharipour, M.; Tavssoli, A. Effect of irrigation with wastewater and foliar fertilizer application on some forage characteristics of foxtail millet (Setaria italica). Int. J. Plant. Physiol. Biochem. 2011, 3, $34-42$.

52. Ghanbari, A.; Abedi, K.; Taei, S. Effect of irrigation with treated wastewater of municipal on yield and quality of wheat and some soil characteristics in sistan region. J. Agric. Sci. Tech. Natur. Res. 2006, 4, 47-59.

53. Kiziloglu, F.; Tuean, M.; Sahin, U.; Angin, I.; Anapali, O.; Okuroglu, M. Effects of wastewater irrigation on soil and cabbage- plant (Brassica olereacea var. capitate cv. Yavola-1) chemical properties. J. Plant. Nutr. Soil Sci. 2007, 170, 166-172. [CrossRef]

54. Khan, M.; Shaukat, S.; Khan, M. Growth, yield and nutrient content of sunflower (Helianthus annuus L.) using treated wastewater from waste stabilization ponds. Pak. J. Bot. 2009, 41, 1391-1399.

55. Omeir, M.; Jafari, A.; Shirmardi, M.; Roosta, H. Effects of irrigation with fish farm effluent on nutrient content of Basil and Purslane. Proc. Natl. Acad. Sci. India Sect. B Biol. Sci. 2020, 90, 825-831. [CrossRef]

56. European Commission. Commission regulation (EC) No. 1881/2006 of 19 December 2006-Setting maximum levels for certain contaminants in foodstuffs. Off. J. Eur. Union 2006, 364, 5. 